\title{
Management of Scientific and Pedagogical Staff as a Factor of Sustainable Development and Increase of Efficiency of the Educational System in the Conditions of Digital Economy Formation
}

\author{
Yulia Romanova \\ Financial University under the Government of the Russian \\ Federation \\ Institute of Market Problems of the Russian Academy of \\ Sciences \\ Moscow, Russia \\ E-mail: Ryulia1@yandex.ru
}

\author{
Irina Sheveleva \\ Pantheon-Sorbonne University \\ Sorbonne, France \\ E-mail: irishev@mail.ru
}

\begin{abstract}
The following paper is concerned with the issues of managing scientific and pedagogical workers and increasing the efficiency of the education system. The qualitative indicators of the teaching staff are crucial for the competitiveness of Russian universities in the international market of educational services. The paper examines not only the qualification and age composition of the scientific and pedagogical staff at universities, but also their involvement in scientific work and international scientific communication. The paper contains the analysis of the work conditions and the scientific and pedagogical contributions of Russian university teachers, and some negative factors that affect the scientific potential of the teaching staff and lead to a decrease in the effectiveness of international interaction, the export of intellectual products.
\end{abstract}

Keywords-scientific and pedagogical potential; the system of education; management; sustainable development

\section{INTRODUCTION}

Over the past 15 years significant changes have taken place in the education system and the personnel policy of higher education institutions. For example, the composition of the teaching staff has become completely different. The constant transformation and reformation of the education system, as well as the unstable economic situation, negatively affected the qualification of the scientific and pedagogical staff of Russian universities. First, it happened because of low wages and lack of incentive measures - a lot of highly qualified teachers emigrated to economically developed countries or retrained and preferred to work in commercial or governmental structures. More than half of the vacant jobs remained for low-qualified teachers, as well as for workers who were not demanded in other areas and came to work at universities for various reasons - reformed institutions or bankrupted enterprises.
In addition, another negative phenomenon in the education system arose due to its funding with whatever funds remained. Because of the inability to adequately pay for the work of scientific workers and teachers, the state gave them the opportunity to obtain academic degrees without much effort. Therefore, "lifelong assistants", failed politicians, directors of trade markets who went bankrupt and the like became candidates of sciences and DSc. In turn, the academic degree lost its value in society and lost its main purpose of professional stratification, increasingly acquiring the function of a "class title." As a result, among the scientific and pedagogical staff of higher education institutions the number of doctors and candidates of sciences doubled for the period from 1992 to 2008 .

The following Russian authors analyzed the issues of managing scientific and pedagogical workers and improving the effectiveness of the education system in their work: Arutyunyan S.A., Babkina L.N., Bakulev S.E., Borisievich M.A., Volodina O.V., Dianov A.A., Kirsanova A.B., Kosinova E.P., Korotenkova R.G., Kochetkova N.N., Metelitsa N.G., Nekhvyadovich E.A., Parfenov Y.A., Popova E.A., Prein O.A. Ryzhbova E.G., Solovtsova M.S., Slobodnyak I.A., Taymazov V.A., Shtanko E.Y., Schennikova M.Y., Yankovskaya V.V., etc.

\section{Changing CONDITIONS FOR TEACHING IN MODERN HIGH SCHOOL}

Let us examine in more detail the influence of global trends on the changes that occur in the field of teaching in the conditions of digital economy formation. One of the main trends in the development of higher education in the world is its orientation to big masses of people or the quantitative growth of students, expressed in the mass striving of the population for higher education. In economically developed countries this trend gives grounds to talk about the transition to universal higher education. Russia, 
despite the lag in its economic development, is part of the leading countries group in terms of the number of students per 10,000 inhabitants, outstripping the United States, Germany and Britain [1].

Massification as a global process for the development of higher education poses several problems related to the conditions of teaching work. The teaching staff of universities should be involved in solving such problems in some ways [2].

- New forms of organization of the educational process, ensuring the implementation of the expanded request for education, including distance education and open educational resources. These forms lead to the following principles:

- Increasing the proportion of independent work of students, which leads to the need to improve the methodological training and methodological support of the educational process, ways to control independent work and organize interaction with students in the process of independent fulfillment of their tasks. This often leads to extending the teachers' working hours as supporting independent work of students may not fit into the scope of the working day. Considering the tendency to increase the teaching load, this additional teaching activity can turn into unpaid work;

- Technological development of the educational process, creation of an educational conveyor operating under conditions of clear organizational and resource regulation;

- Implementation of an independent assessment of knowledge at all stages of training and after its completion.

- Strengthening the heterogeneity and organizational diversity of forms of universities. The institutional sphere of higher education development in recent years has been characterized by the possibilities of various trajectories of developing the university. These are the new or modernized development models:

- Universities which develop knowledge-based and innovative industries and technology parks in their structure. In various classifications of universities, such models are called entrepreneurial universities, innovative, innovative-entrepreneurial, etc.;

- Universities that resemble vertically integrated holdings to include in their structure divisions from kindergarten to institutions of retraining and graduate education;

- Sectoral universities that support business in the corresponding service sector;

- Universities that integrate the education system on their territory; institutions

- Universities that are also scientific

- $\quad$ Corporate universities.

The variety of models for developing universities today poses a problem of choosing "their own" university in front of university teachers. Such a university should comply with the teacher's personal strategies of professional development, social experience, research and teaching skills [3].

\section{TECHNOLOGICAL MODERNIZATION OF SCIENTIFIC AND PEDAGOGICAL WORK}

Important changes are taking place in the technology of training specialists with higher education. The acceleration of scientific and technological progress has a revolutionizing impact on the technology of producing and transferring knowledge and is the main pre-requisite for the need to reform and manage education [4].

The new information society forms its requirements for universities both as systems of producing and transferring knowledge, and as management systems. The information society is often called a "continuously learning society", which presents qualitatively new requirements to education, which should result in the development of abilities to master, expand and improve new activities and corresponding new knowledge and skills [5].

In this context, today in the universities there are two tasks to be solved [6]:

- Managing the informatization of education as managing a complex of activities related to the saturation of the educational system with information tools, technologies and products;

- Informatization of university management as a set of measures to ensure the effectiveness of university management on the basis of modern information technologies.

Thus, an adequate response of universities to external challenges today is impossible without radical restructuring and updating the training technologies and management systems of the university. Modernization in this sphere ensures the adaptation of the university to the new economic and social conditions and should be based on developing the capacity of universities to identify new strategic development targets for the future, conditioned by information technologies, the new competencies of the NDP for the application of information educational technologies and modern management technologies, potential of the university, etc.

The problems of wide introduction and development of information systems in universities are related to two factors. The first is the need to improve the skills of staff, the inculcation of modern information literacy and culture. The second is a fairly high cost of the process (payment for services of external development companies and own highly skilled IT specialists) [7]. 
Information technologies are in the process of continuous improvement, and these dynamics poses new challenges for education and initiates the creation of increasingly sophisticated tools and teaching technologies that facilitate their solution. Universities actively introduce information technologies of education, distance education technologies, active forms of education, etc. to ensure the training of "flexible" specialists that are demanded in the modern dynamically changing labor market.

Learning technologies based on the transfer of knowledge are gradually being replaced by the technologies of forming in students a set of competencies which relate to the development of certain knowledge and skills that are required in the international labor market.

The pace of technological progress is now beginning to increasingly influence the effectiveness of the education system, which, in turn, cannot but change, reflecting the new demands of society, conditioned by the development of science and production [8].

Changes that have occurred in recent years in the field of higher education are diverse and reflect regional, national and local specifics. Nevertheless, we can conclude that there are general trends in the development of scientific and educational activities of higher education institutions in foreign countries.

Russian higher education generally repeats the world tendencies of transition from the higher school of industrial design to the higher school of the postindustrial era, as evidenced by a number of trends that have developed over the past few years:

Higher education in Russia is becoming increasingly massive. Since the 1990s, the number of universities in the country has doubled, and the number of students has increased by almost 2.5 times, which has an undoubted positive effect for Russian society. However, the peculiarity of the transition to mass higher education in the Russian Federation is that it occurs simultaneously with the protracted demographic decline and a very uncertain economic situation.

Besides, Russian higher education is rapidly commercialized, which is also a worldwide trend. The growth of the paid education sector in Russia has been going on since the mid-1990s, and its development is very rapid. Domestic universities are gradually transforming into market entities and begin to act accordingly [9].

The high dynamics of external processes and their globalization are currently obvious and stable characteristics of the conditions of higher education teaching activity. Adaptation to the ever-changing external environment is the minimum task for universities. Leading universities should focus on anticipation and implement advanced programs for their activities. In this regard, the key requirements for universities are the ability to self-develop, flexibility, and adaptability [10].

New challenges of the external environment, which make it necessary to improve the quality of university management based on a number of modern management technologies, are systemic in nature and are formed in all key spheres: economy, politics, society and technologies.

An important factor in changing the external environment is strengthening the market foundations of university activity and the growing competition for limited resources between universities. This is due to the following factors:

- The number of school leavers is decreasing because of demographic problems;

- Teaching resource turned out to be inefficient, moreover, it has been poorly replenished in recent years due to the noncompetitiveness of salaries in higher education with those in some other sectors of the economy;

- Financial support for education will increasingly be implemented on the basis of project and competitive financing.

All these circumstances clearly demonstrate the need to develop and adopt long-term measures that provide competitive advantages in the struggle for resources.

The process of learning has also changed. Universities are beginning to focus on the preparation of "flexible" specialists in demand on the labor market, and accordingly change the technology of teaching. Companies need employees who can solve problems related to different branches of knowledge and have the skills to adapt to the rapid change of labor. Therefore, the emphasis in vocational training is gradually shifting from the transfer of qualifications as a set of knowledge formally confirmed by the diploma to the transfer of a set of competences.

\section{CONCLUSION}

Changes in the conditions of scientific and pedagogical work of higher school employees are connected with developing the new forms of educational process organization that are needed because of the expanded demand for education, including distance education and open educational resources. Heterogeneity and organizational diversity in the forms of higher education institutions are strengthened and teaching work is technologically modernized.

The ongoing change in the content of teaching work is directly related to the formation of new educational strategies and policies by universities. In terms of content, it includes a change in the structure of employment and the teaching load of university staff, as well as creating new educational resources and content that meets the specific needs of different categories of trainees.

To determine further steps in the development of the national higher education system, Russia still has to learn to deal with a number of issues: to decide whether to carry out a radical reform of the education system or to leave the system to evolve, to introduce general reforms of universities budget financing; to regulate the system or to let it be regulated by 
the market; to import the most advanced samples of universities or to try to build those of our own, etc.

\section{REFERENCES}

[1] O.V. Volodina, Loyalty management as a way to improve the efficiency of the teaching staff of the university. In the collection: Humanitarian readings of Russian State University for the Humanities - 2016 Collection of materials. Ministry of Education and Science of the Russian Federation, Federal State Budget Educational Institution of Higher Education "Russian State Humanitarian University", 2017, pp. 154-163.

[2] S.A., Arutyunyan, N.N. Kochetkova, Methodological aspect of the evaluation of the effectiveness of the teaching staff of the university. Competitiveness in the global world: economy, science, technology. 2017. No. 6-2 (50), pp. 10-14.

[3] M.Y. Shchennikova, S.E. Bakulev, V.A. Taymazov, M.A. Borisevich, Estimates of the effectiveness of the work of the teaching staff as a tool for targeted management. Scientific notes of the University. Named after P.F. Lesgaft. 2017, No. 4 (146). pp. 264-270.

[4] V.V. Yankovskaya, L.N. Babkina, Features of an estimation of a professional result of work of pedagogical shots. Economy. Business. Banks. 2017, Vol. 1, pp. 60-72.

[5] E.A. Nekhvyadovich, A.B. Kirsanova, E.P. Kosinova, Y.A. Parfenov, R.G. Korotenkova, Analysis and optimization of professional motivation of the university staff. Scientific notes of the University named after P.F. Lesgaft. 2015. No. 5 (123). pp. 232-236.

[6] World University Rankings 2016-2017 / Times Higher Education. https://www.timeshighereducation.com/world-universityrankings/2017/world-

ranking\#!/page/0/length/25/sort_by/rank/sort_order/asc/cols/stats. [45]

[7] World University Rankings 2016-2017 / Times Higher Education. https://www.timeshighereducation.com/world-universityrankings/2017/worldranking\#!/page/0/length/25/sort_by/rank/sort_order/asc/cols/stats. [47]

[8] E.A. Popova E.A, M.S. Solovtsova, E.Y. Shtanko, Material incentives for teachers as one of the factors of the university's competitiveness. The humanitarian bulletin of the Military Academy of Strategic Missile Forces. No. 2 (6). pp. 141-147.

[9] I.A. Slobodnyak, O.A. Preina, Evaluation of the effectiveness of the teacher. Economics and management: problems, solutions. 2015, No. pp. 36-50.

[10] TIMSS - Trends in Mathematics and Science Study, International study on the evaluation of the quality of mathematical and natural science education, conducted by an international educational center IEA's TIMSS \&PIRLS (Boston, USA). TIMSS 2015 International Results Report / TIMSS \& PIRLS International Study Center. - 2015. -http://timssandpirls.bc.edu/timss2015/internationalresults/download-center/. 